\title{
Knowledge and perception of pelung keepers's toward chicken contests in West Java, Indonesia
}

\author{
INDRAWATI Y. ASMARA ${ }^{1}$, DANI GARNIDA ${ }^{\mathbf{1}}$, MARINA SULISYTATI ${ }^{1}$, SAFITRI TEJANINGSIH ${ }^{\mathbf{1}}$, \\ RUHYAT PARTASASMITA ${ }^{2, \varphi}$ \\ ${ }^{1}$ Faculty of Animal Husbandry, Universitas Padjadjaran. Jl. Raya Bandung-Sumedang Km. 21, Jatinangor, Sumedang 45363, West Java, Indonesia \\ ${ }^{2}$ Department of Biology, Faculty of Mathematics and Natural Sciences, Universitas Padjadjaran. Jl. Raya Bandung-Sumedang Km. 21, Jatinangor, \\ Sumedang 45363, West Java, Indonesia. Tel./fax.: +62-284-288828. •email: ruhyat.partasasmita@unpad.ac.id; rp2010rikkyo@gmail.com
}

Manuscript received: 5 May 2018. Revision accepted: 10 November 2018

\begin{abstract}
Asmara IY, Garnida D, Sulisytati M, Tejaningsih S, Partasasmita R. 2018. Knowledge and perception of pelung keepers's toward chicken contests in West Java, Indonesia. Biodiversitas 19: 2232-2237. Pelung chicken is an indigenous chicken breed which has social and cultural functions in particular communities in Indonesia. Contests are conducted regularly as a media to show the singing ability of Pelung chickens and the activities are considered important to maintain the existence of the chickens. The objective of this study was to determine the knowledge and perceptions of chicken keepers toward chicken contests for Pelung chickens. A survey using open and structured questionnaire was conducted to collect data involving 133 Pelung keepers. The study was carried out in four districts in West Java Province, Indonesia including Cianjur, Sukabumi, Bandung, and Garut Districts. The data were analyzed using descriptive analysis. The result showed that almost respondents knew about contests and they defined contests as a media to find good breeds as well as a media to find and/or improve networks. Main sources of information contests were the organization, family, and social media. Respondents had positive perception toward contests, and they actively participated in the different level of contests. The findings are important as social input for the management of animal genetic resources (AnGR) in Indonesia
\end{abstract}

Keywords: Contests, knowledge, Pelung chicken keepers, perception, West Java

\section{INTRODUCTION}

Indigenous chicken breeds form part of global Animal Genetic Resources (AnGR). It was reported that indigenous chickens in Indonesia differ from those in Asia and other countries in the world; thus, Indonesia was considered as one of the major chicken domestication centers in the world, besides China and India. (Sulandari et al. 2007a; 2008). Indigenous chicken breeds are a national resource and make a significant contribution to food security and the livelihoods of people in rural areas (Director General of Livestock Services 2003). They also perform social and cultural functions in particular Indonesian communities (Iskandar et al. 2004; Partasasmita et al. 2017).

In Indonesia, there are at least 31 distinct groups of indigenous chickens in Indonesia (Nataamijaya 2000; Partasasmita et al. 2016), which are generally classified into two groups: descript and nondescript chickens (Directorate General of Livestock Services 2003). Descript chickens have specific characteristics primarily related to their plumage and are regarded as local to a specific area (Diwyanto and Iskandar 1999). Non-descript chickens have no specific phenotypical characteristics. These chickens can be found in most villages (kampung) in Indonesia (Nataamijaya 2000), so they are commonly known as 'kampung chickens'.

The populations of indigenous chicken breeds in Indonesia are assumed to be in decline (Diwyanto and Prijono 2007). Breeds were found to be less likely to be at risk where they had specific traits that permitted them to make an important contribution to farmer livelihoods, including through their role in broader religious and/or traditional customs in the communities (Asmara 2014; Asmara et al. 2014). Pelung chickens are among other chickens in Indonesia which at risk of extinction; however, this breed has specific characteristics in relation to cultural aspect.

Pelung chicken is originally from Cianjur District in West Java Province raised as singing chickens (Muladno 2008; Sulandari et al. 2007b). Most of Pelung keepers in Cianjur raised their chickens for cultural motivation. The existence of singing contests makes more people interest in keeping the chickens and their distribution grows outside their original areas. As a result, the existence of contests is very important in the conservation of indigenous chicken breeds in Indonesia (Asmara 2014). Pelung contests, which were conducted regularly at local to national level, were marketplaces for Pelung chickens (Hippapi 2005). During contests, Pelung chickens were traded. If the chickens won the contests, their prices increased. In addition, the fertile eggs and/or offspring of the contest-winning chickens and their dams were valued more highly (Asmara 2014). The Pelung trading in contests not only involve the keepers but also traders and or fanciers; thus, is not strange if the contests shifting from cultural events into the economic event only. Keepers can be viewed as de facto conservation agents for agricultural genetic resources (FAO 2012; Narloch et al. 2011). The perceptions and knowledge of contests can be implemented as input for contest management. Therefore, the objective of this study was to determine the perceptions and knowledge of farmers on 
chicken contests.

\section{MATERIALS AND METHODS}

\section{Study area}

The research was conducted in four districts in the West Java Province, Indonesia, i.e., Cianjur, Sukabumi, Bandung, and Garut Districts (Figure 1), where Pelung chickens were majority kept. ). Cianjur and Sukabumi Districts are in southwestern Java Island. Cianjur District is adjacent with Sukabumi District and is situated at an altitude of 7-2,962 m with mean annual rainfall of 2,610 $\mathrm{mm}$ and mean annual temperature $24.4^{\circ} \mathrm{C}$ (Cianjur District Office of Information Communication and Statistics 2017). Sukabumi is situated at an altitude of $0-2,960 \mathrm{~m}$ with annual rainfall of 2,000-4,000 mm and annual temperature $18-30^{\circ} \mathrm{C}$ (Sukabumi District Government 2017). Bandung District is adjacent with the capital of West Java Province, Bandung City, and is a highland area with annual rainfall $1,500-4,000 \mathrm{~mm}$ with annual temperature between $12-24^{\circ} \mathrm{C}$ (Bandung District Government 2017). Garut District is adjacent with Bandung District located $64.2 \mathrm{~km}$ from the capital of West Java Province. The district is situated at an altitude $100-1500 \mathrm{~m}$ with mean annual rainfall $2,589 \mathrm{~mm}$ and annual temperature $24-27^{\circ} \mathrm{C}$ (Garut District Office of Information Communication and Statistics 2017).
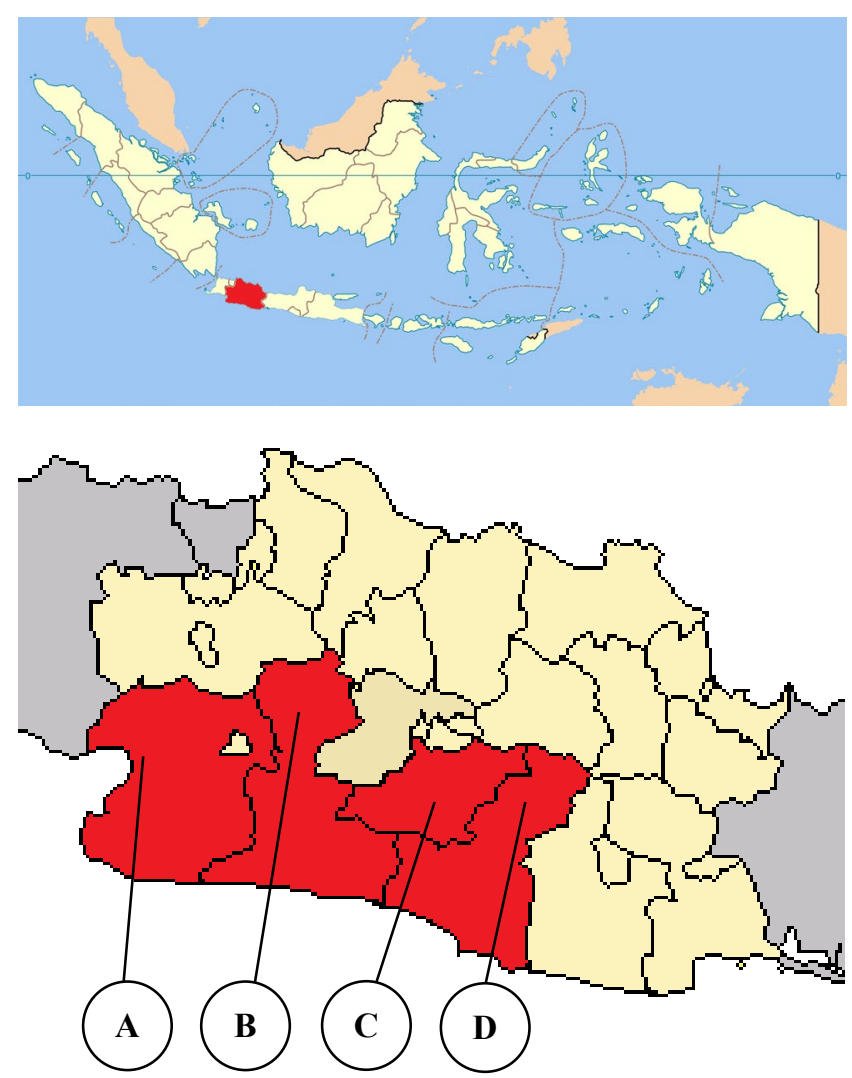

Figure 1. Research locations in West Java, Indonesia. A. Sukabumi, B. Cianjur, C. Bandung, D. Garut

\section{Procedures}

Interviews were the main data-collection technique involving key informants as well as keepers of Pelung chickens. First, open interviews were conducted with the key informants to help determine the current situation of the case-study breed and to select the area and the keepers to be involved in the study. Second, face-to-face interviews with a structured and open questionnaire were used to collect information from the farmers about their knowledge and perceptions on chicken contests. The respondents in the study were households in which the person who owned the chickens was interviewed. In this research, purposive sampling was conducted rather than random sampling because of no exact information about the number of keepers for Pelung. A total of 133 male respondents consisting of 33, 25, 36, and 39 respondents in Cianjur, Sukabumi, Bandung, and Garut Districts, respectively, participated in the survey. All quantitative data collected from the questionnaire were coded and prepared for further analysis (descriptive analysis) using the Statistical Package for the Social Sciences (SPSS) IBM SPSS statistics 19 (Pallant 2011).

\section{RESULTS AND DISCUSSION}

\section{Respondents' social demographic information}

Table 1 shows the socio-demographic characteristics of the 133 farmers who participated in the study. The male respondents were aged between $15-59$ years old $(83.46 \%)$. About $32 \%$ respondents were educated at elementary school level, more than $40 \%$ of respondents were educated up to senior high school and even more than $15 \%$ of respondents reached higher education level (Diploma and Bachelor degree). A total of $36 \%$ of respondent had farming experience between 3.5-10 years, followed by respondents who had farming experience more than 17.5 years $(27.07 \%)$ and less than 3.5 years $(23.31 \%)$. The main jobs of the respondents were variously dominated by selfemployee (29.32\%) and farmers (32.33\%).

\section{Respondent knowledge and perception toward pelung contests}

Table 2 shows respondent knowledge about chicken contests resulted in from open questions. Almost all respondents knew about chicken contests (96.24\%). A various of statements occurred when respondents were asked about their perceptions toward contests. More than $40 \%$ of respondents defined contest as a media to find good breeds, $19.53 \%$ of respondents defined contest as a media to find and/or improve networks, $17.97 \%$ of respondents defined contest as media for showing chicken's sound and about $13 \%$ of respondents defined contest as part of their hobby in keeping Pelung chickens. Other definitions such as a media to increase chicken selling price $(3.91 \%)$, a media for self-existence $(3.12 \%)$ and a media to get prize $(0.78 \%)$ also occurred.

Respondents who knew about chicken contests were asked about their participation and source of information about contests. Respondents who participated in contests 
then were asked about their level of participation and motivation to participate in contests. More than $80 \%$ of respondents participated in contests and they joined contests mostly at district level. Respondents had information about the contests from different sources such as farmer group, social media and family. The motivation of respondents to join contests were dominated by their willingness to find and/or improve networks $(65.38 \%)$ and to improve knowledge and experience in keeping Pelung $(28.85 \%)$. Table 3 displays participation, source of information, level of contests and motivations of respondents in joining contests.

Table 4 shows a Likert scale to gauge respondents' perceptions about contests. For statement "Pelung keepers must participate in contests", more than $65 \%$ of respondents "agreed" and "strongly agreed" and majority of respondents (88.38\%) "agreed" and "strongly agreed" with statement "More contests are better". More than $60 \%$ of respondents "agreed" and "strongly agreed" with statement "I will join contests as much as I can", while for statement "Information about contests is very important", majority of respondents (89.85\%) "agreed" and "strongly agreed". About $85 \%$ of respondents "agreed" and "strongly agreed" with statement "It is easy to participate in contests".

In terms of statement "To be winner contests is my only motivation in raising Pelung Chickens", more than $50 \%$ of respondents "agreed" and "strongly agreed", a same number of respondents (more than 20\% each) "neither agreed nor disagreed" and "disagreed" correspondingly with the statement. Almost all respondents (95.31\%) "agreed" and "strongly agreed" with statement "Contest is an effective media for increasing selling price". Majority of respondents $(87.50 \%)$ "agreed" and "strongly agreed", with statement "Contest is a good media for increasing knowledge about Pelung management". Almost half of respondents (48.44\%) "agreed" with statement "I will never sell my winning chicken contests", while $20.31 \%$ of respondents "disagreed" and $31.25 \%$ of respondents "neither agreed nor disagreed" with the statement.

Table 1. Socio-economic characteristics of respondents

\begin{tabular}{|c|c|c|c|c|c|}
\hline \multirow{3}{*}{ Item } & \multicolumn{4}{|c|}{ District } & \multirow{2}{*}{ All district } \\
\hline & Garut & Bandung & Cianjur & Sukabumi & \\
\hline & \multicolumn{5}{|c|}{$(\%)$} \\
\hline \multicolumn{6}{|l|}{ Age (years) } \\
\hline $15-59$ & 75.76 & 80.77 & 88.89 & 87.18 & 83.46 \\
\hline$>59$ & 24.24 & 19.23 & 11.11 & 12.82 & 16.54 \\
\hline \multicolumn{6}{|l|}{ Education } \\
\hline No education & 0 & 0 & 0 & 2.56 & 0.75 \\
\hline Elementary School & 33.34 & 4.00 & 63.89 & 20.51 & 32.33 \\
\hline Junior High School & 30.30 & 16.00 & 22.22 & 7.70 & 18.80 \\
\hline Senior High School & 15.15 & 28.00 & 11.11 & 64.10 & 30.83 \\
\hline Diploma & 18.18 & 12.00 & 2.78 & 5.13 & 9.02 \\
\hline Bachelor & 3.03 & 40.00 & 0 & 0 & 8.27 \\
\hline \multicolumn{6}{|c|}{ Farming experience (years) } \\
\hline $1-3.5$ & 12.12 & 36.00 & 22.22 & 25.64 & 23.31 \\
\hline$>3.5-10$ & 24.24 & 24.00 & 55.55 & 35.90 & 36.09 \\
\hline$>10-17.5$ & 18.18 & 16.00 & 05.06 & 15.38 & 13.53 \\
\hline$>17.5$ & 45.46 & 24.00 & 16.17 & 23.08 & 27.07 \\
\hline \multicolumn{6}{|l|}{ Main job } \\
\hline Farmer & 27.27 & 8.00 & 50.00 & 35.90 & 32.33 \\
\hline Laborer & 18.18 & 4.00 & 33.33 & 17.95 & 19.55 \\
\hline Employee & 21.21 & 40.00 & 0 & 20.51 & 18.80 \\
\hline Self-employee & 33.34 & 48.00 & 16.67 & 25.64 & 29.32 \\
\hline
\end{tabular}

Table 2. Knowledge of respondents toward contests

\begin{tabular}{|c|c|c|c|c|c|}
\hline \multirow{3}{*}{ Statement/Question } & \multicolumn{4}{|c|}{ District } & \multirow{2}{*}{ All districts } \\
\hline & Garut & Bandung & Cianjur & Sukabumi & \\
\hline & \multicolumn{5}{|c|}{$(\%)$} \\
\hline \multicolumn{6}{|l|}{ Do you know about Pelung contest? } \\
\hline Yes & 97.00 & 96.00 & 100 & 92.31 & 96.24 \\
\hline No & 3.00 & 4.00 & 0 & 7.69 & 3.76 \\
\hline \multicolumn{6}{|l|}{ What do you know about contest? } \\
\hline Media for showing chicken's sound & 12.50 & 0 & 2.78 & 50.00 & 17.97 \\
\hline Media to find good breeds & 34.38 & 50.00 & 66.67 & 16.67 & 41.41 \\
\hline Part of hobby & 6.25 & 12.50 & 13.89 & 19.44 & 13.28 \\
\hline Media to find/improve network & 37.50 & 29.17 & 8.33 & 8.33 & 19.53 \\
\hline Media to get prize & 0 & 0 & 0 & 2.78 & 0.78 \\
\hline Media to increase selling price & 0 & 8.33 & 5.56 & 2.78 & 3.91 \\
\hline Media for self-existence & 9.37 & 0 & 2.77 & 0.00 & 3.12 \\
\hline
\end{tabular}


Table 3. Participation, source of information, level of participation and motivation to participate in contests

\begin{tabular}{|c|c|c|c|c|c|}
\hline \multirow[b]{2}{*}{ Statement/Question } & \multicolumn{4}{|c|}{ District } & \multirow{2}{*}{ All districts } \\
\hline & Garut & Bandung & $\begin{array}{r}\text { Cianjur } \\
(\%)\end{array}$ & Sukabumi & \\
\hline \multicolumn{6}{|l|}{ Do you participate in contests? } \\
\hline Yes & 93.75 & 91.67 & 66.67 & 77.78 & 81.25 \\
\hline No & 6.25 & 8.33 & 33.33 & 22.22 & 18.75 \\
\hline \multicolumn{6}{|l|}{ Source of contest information } \\
\hline Organization (farmer group) & 53.13 & 37.50 & 38.89 & 22.22 & 37.50 \\
\hline Social media & 15.63 & 20.83 & 44.45 & 44.44 & 32.81 \\
\hline Family & 21.86 & 41.67 & 08.33 & 30.56 & 24.22 \\
\hline Invitation & 09.38 & 0 & 08.33 & 0 & 4.69 \\
\hline Others & 0 & 0 & 0 & 2.78 & 0.78 \\
\hline \multicolumn{6}{|l|}{ Level of participation (ranking) } \\
\hline District & 93.33 & 95.45 & 91.67 & 89.29 & 92.31 \\
\hline Province & 66.67 & 77.27 & 58.33 & 64.29 & 66.35 \\
\hline National & 76.67 & 63.64 & 41.67 & 67.86 & 63.46 \\
\hline \multicolumn{6}{|l|}{ Motivation to participate in contests } \\
\hline To improve knowledge and experience & 33.33 & 13.64 & 20.83 & 42.86 & 28.85 \\
\hline To find/improve networking & 63.33 & 86.36 & 70.83 & 46.43 & 65.38 \\
\hline To get prize & 3.34 & 0 & 4.17 & 7.14 & 3.85 \\
\hline To have popularity & 0 & 0 & 4.17 & 3.57 & 1.92 \\
\hline
\end{tabular}

Table 4. Perception of respondents toward contests

\begin{tabular}{|c|c|c|c|c|c|}
\hline Statement/Question & $\begin{array}{l}\text { Strongly } \\
\text { disagree }\end{array}$ & Disagree & $\begin{array}{c}\text { Neutral } \\
(\%)\end{array}$ & Agree & $\begin{array}{c}\text { Strongly } \\
\text { agree }\end{array}$ \\
\hline Pelung keepers must participate in contests & 7.03 & 9.37 & 16.41 & 35.94 & 31.25 \\
\hline More contests are better & 0 & 2.34 & 9.38 & 42.19 & 46.19 \\
\hline I will join contests as much as I can & 3.91 & 9.38 & 25.78 & 33.59 & 27.34 \\
\hline Information about contests is very important & 0.78 & 0.78 & 8.59 & 36.72 & 53.13 \\
\hline It is easy to participate in contests & 1.56 & 1.56 & 10.94 & 53.13 & 32.81 \\
\hline To be winner contests is my only motivation in raising Pelung Chickens & 2.34 & 19.53 & 22.66 & 30.47 & 25.00 \\
\hline Contest is an effective media for increasing selling price & 0 & 0 & 4.69 & 40.62 & 54.69 \\
\hline Contest is a good media for increasing knowledge about Pelung mangement & 0 & 1.56 & 10.94 & 52.34 & 35.16 \\
\hline I will never sell my winning chicken contests & 13.28 & 17.97 & 20.31 & 23.44 & 25.00 \\
\hline
\end{tabular}

\section{Discussion}

This current study revealed that Pelung keepers were dominated by male keepers. Domination of male in poultry farming was found in study of Jansen et al. (2009), Dana et al. (2010) and Okeno et al. (2012). In the current study, domination of male keepers may be due to the sociocultural aspect of Pelung. Pelung had been part of the men's lifestyle in Cianjur and, nowadays in other areas in West Java. Asmara (2014) stated that Pelung keepers raised their chickens as fancy chickens. The keepers spent their spare time listening to their chickens singing and looking after them. However, Asmara (2014) found that women are involved in raising Pelung chickens, even though their roles are not clearly articulated. Guèye (2005) named this situation as 'gender blindness' because women contribution in poultry smallholder is 'invisible'. The patriarchal norms which shape gender roles and responsibilities may contribute to this situation because of which, farming is perceived as activities ruled by men (Galiè et al. 2013).
Women contribution and motivation in raising Pelung should be further investigated.

This study also revealed that Pelung keepers are varied in terms of age, education, farming experience and occupations. Uneducated keepers are not dominant, and the age of the keepers are relatively young. Age (Govindasamy and Italia 1999; Vanslembrouck et al. 2002), and education (Vanslembrouck et al. 2002) are two important aspects in adopting program or innovation in agriculture. Younger and better-educated farmers are more positive in accepting agricultural policies (Vanslembrouck et al. 2002). Pelung keepers are dominated by experienced people in maintaining Pelung chickens. Keepers with more farming experiences are assumed to have better knowledge and information to use in the adaptation of environment and socioeconomic conditions (Hassan and Nhemachena 2008; cf. Partasasmita et al. 2016, 2017). In the past, Pelung chickens were only kept by particular people in Cianjur Region such as religious leaders or local people named them Kyai (Hippapi 2005). Recently, as it is revealed in the 
current study, the occupation of Pelung keepers is varied since Pelung chickens are considered as fancy chickens due to their singing capability. Thus, the chicken distribution is wider compared to other indigenous chickens. Even though, indigenous chickens in Indonesia is considered at risk of extinction; Pelung chickens are assumed to be safer compared to other chickens such as Kedu and Sentul chickens (Asmara 2014; Asmara et al. 2014).

In the current study, Pelung keepers define contests as a media to find good breeds. In general, good Pelung chickens have initial, middle and closing sound and they can crow for 15 seconds, while other chickens only 2-3 seconds (Hippapi 2005). This finding supported finding stated by Asmara (2014) who reported that contests were part of the market route of Pelung chickens. Asmara (2014) argued that the transaction of Pelung chickens did not occur in conventional markets. For experienced buyers, the one who can recognize good chickens from their physical characteristics and/or sound, contest is considered as market to find good breeds. Experienced buyers also had enough information about the owners of contest-winning chickens. Unlike experienced buyers, regular buyers usually involved agent to find good breeds and transaction did not occur in contests.

In the present study, keepers also define contest as media to find and/or improve networks. Motivation to participate in contests is also determined by finding networks. The network can be defined as "any collected actors that pursue repeated enduring exchange relations with one another and, at the same time, lack a legitimate organizational authority to arbitrate and resolve disputes that may arise during the exchange" (Podolny and Page 1998). Network can be seen as informal knowledge building and transfer which part of the knowledge system and it is important to make agricultural activities more sustainable (Š̄umane et al. 2017). In this situation, farmers are more active since they generate information not only act as passive receivers. Beside improving networks, the motivation of respondents to join contests were dominated by their willingness to improve knowledge and experience in keeping Pelung. Stuiver et al. (2004) define farmers' knowledge as "the capability of a farmer to co-ordinate and to (re-) mould a wide range of socio-technical growth factors within specific localities and networks towards desired outcomes (e.g. sustainable levels of production)". Vik and Straete (2017) proposed the typology of farmers that actively pursues knowledge as 'the knowledge seeking farmer'. This type of farmers is willing to improve knowledge from different sources and they usually have high degree formal education. In general, practical experiences, as well as successful colleagues, are important knowledge sources for farmers because of similar practical experience condition (Šūmane et al. 2017).

The current study indicates that Pelung keepers have information about contest from several sources including farmer organization, family and social media. FAO (2014) defined farmer organization as "a formal or informal membership-based collective action institution serving its members, who are rural dwellers that get part or all of their livelihood from agriculture". Farmer organization is important in terms of providing access to advice, information, markets, inputs, and advocacy. Most of Pelung keepers are member of Himpunan Peternak dan Penggemar Ayam Pelung Indonesia or HIPPAPI which covered some districts in West Java and Banten Provinces. The organization is a media for members to share their knowledge and experiences in keeping and marketing Pelung chickens as well as make them well informed in terms of government and or other institution programs (Asmara 2014). Family is also the main source of information for contest. In family farmers in which family members contribute in managing farm operation, transfer information and knowledge usually occurred (Garner and Compos 2014). For some countries, family is a central of knowledge and learning decision for farmers since their initial knowledge are derived from parents and grandparents (Šūmane et al. 2017; Partasasmita et al. 2017). Another interesting finding in current study is contribution of social media in providing contest information. Social media enable people in communication and sharing information using internet-based digital tools. The role of social media in sharing information and connecting farmers is important not only in developed countries but also in developing countries. Facebook is a major form of social media for farmers in India (Jijina and Raju 2016) and United States of America (Cui 2016).

Pelung keepers have positive perception toward contests. Their positive perception can be seen from the function of contests as media for increasing economic value of Pelung chickens. The economic importance of contests was reported by Asmara (2014) and Muladno (2008) who stated contests as one of the important marketing channels in the business of Pelung. The number of contests outgrowth marketing of Pelung and very effective events to introduce Pelung mainly the winning contests to the wider community. The winner of the contest can certainly have a high selling value and offspring of the winners sold for higher prices than those of non-winners (Muladno 2008; Asmara 2014). The economic dependency of keepers to their chickens make contests become the important instrument for maintaining indigenous breeds. In this study, contests also perceived as media for sharing of knowledge between keepers. This horizontal transfer of knowledge (between farmers) combined with the vertical transfer of knowledge (example from universities or other institutions) will help to strengthen the capacity building process of Pelung keepers.

It examines keepers' perception toward contests and the findings fill the gap of social studies of animal genetic resources in order to safeguard indigenous chicken breeds in the future. The study indicates some important findings including the importance of contests perceived by Pelung keepers not only from economic but also from social perspectives. Further studies should be conducted mainly on women contribution in Pelung management as well as the mechanism of transfer of knowledge between keepers in contests. Furthermore, investigations regarding women contribution in Pelung management and knowledge transfer between keepers in contests should be carried in the future. 


\section{ACKNOWLEDGEMENTS}

We would like to thank Universitas Padjadjaran, Bandung, Indonesia through Hibah Internal Unpad (HIU) for funding this study.

\section{REFERENCES}

Asmara IY, Greiner R, Drucker AG. 2014. Indigenous chicken breeds in Indonesia: Extinction of risk status, driving factors and implication for conservation. Proceeding the $16^{\text {th }}$ AAAP: Sustainable livestock production in perspective of food security, policy, genetic resources, and climate change. Yogyakarta, 10-14 November 2014. Cui Y. 2014 Examining farmers markets' usage of social media: An investigation of farmers market Facebook page, J Agric Food Syst Community Dev 5 (1): 87-103.

Asmara IY. 2014. Risk Status of Selected Indigenous Chicken Breeds in Java, Indonesia: Challenges and Opportunities for Conservation. [Disertation]. Research Institute for the Environment and Livelihoods, Faculty of Engineering, Health, Science and the Environment Charles Darwin University, Darwin, NT, Australia

Bandung District Government. 2017. Geography and Demography. Bandung District Government, Soreang.[Indonesian]

Cianjur District Office of Information Communication and Statistics 2017. Geographical location, https://cianjurkab.go.id/profilcianjur/letak-geografis/. [Indonesian]

Dana N, Waaij LH, Dessie T, Arendonk JAM. 2010. Production objectives and trait preferences of village poultry producers of Ethiopia: implications for designing breeding schemes utilizing indigenous chicken genetic resources'. Trop Anim Health Prod 42 (7): 1519-1529.

Director General of Livestock Services. 2003. National Report on Anima Genetic Resources Indonesia: A Strategic Policy Document. the Ministry of Agriculture of the Republic of Indonesia, Jakarta, Indonesia

Diwyanto K, Iskandar S. 1999. 'Kampung chickens: a key part of Indonesia's livestock sector', in Livestock industries of Indonesia prior to the Asian financial crisis, FAO. www.fao.org/docrep/004/ab986e/ab986e03.htm.

Diwyanto K, Prijono SN. (eds) 2007. Genetic Resources Diversity of Local Chickens in Indonesia. LIPI Press, Jakarta. [Indonesian]

FAO. 2012. Roles of small-scale livestock keepers in the conservation and sustainable use of animal genetic resources, Commission on Genetic Resources for Food and Agriculture, Rome, Italy.

FAO. 2014. Farmers' organizations in Bangladesh: A mapping and capacity assessment. Food and Agriculture Organization of the United Nations, Rome.

Galiè A, Jiggins J, Struik PC. 2013. Women's identify as farmers: a case study of ten households in Syria. NJASWagen J Life Sci 64-5: 25-33.

Garner E, Campos APO. 2014. Identifying the "Family Farm": An Informal Discussion of the Concepts and Definitions. ESA Working Paper No. 14-10. FAO, Rome.

Garut District Office of Information Communication and Statistics. 2017. Geographical location, Garut District Office of Information Communication and Statistics, Garut_[Indonesian]

Govindasamy R, Italia JJ. 1999. Predicting willingness-to-pay a premium for organically grown fresh produce. J Food Distrib Res 30 (2): 4455.

Guèye EF. 2005. Gender aspects in family poultry management systems in developing countries, Worlds Poult Sci J 61 (1): 39-46.

Hassan R, Nhemachena C. 2008. Determinants of African farmers' strategies for adapting to climate change: Multinomial choice analysis. Afjare 2 (1): 83-104.
Hippapi. 2005. Enchanting of animal genetic resources in Cianjur. Hippapi of Cianjur District, Cianjur, Indonesia. [Indonesian]

Iskandar S, Setioko AR, Sopiyana S, Sartika T, Saepudin Y, Wahyu E, Hernawati R, Mardiah E. 2004. In-situ conservation for Pelung chickens, Sentul chickens and Kedu chickens and quantitative and qualitative characteristics of Sedayu, Wareng and Ciparage chickens. Livestock Research Center, Agency for Agricultural Research and Development, Ministry of Agriculture, Bogor, Indonesia. [Indonesian]

Jansen T, Glatz PC, Miao ZH. 2009. A survey of village poultry production in the Solomon Islands. Trop Anim Health Prod 41:13631370

Jijina CK, Raju G. 2016. Social media and farmers. Int J Res Eng Technol 5 (19): 20-25.

Muladno. 2008. Local chicken genetic resources and production systems in Indonesia. Food and Agriculture Organization of the United Nations, Rome, Italy.

Narloch U, Pascual U, Drucker AG. 2011. Cost-effectiveness targeting under multiple conservation goals and equity considerations in the Andes. Environ Conserv 38 (4): 417-425.

Nataamijaya AG. 2000. The native chicken of Indonesia. Bull Germ Plasm 6 (1): 16

Okeno TO, Kahi AK, Peters KJ. 2012. Characterization of indigenous chicken production systems in Kenya. Trop Anim Health Prod 44: 601-608.

Pallant J. 2011. SPSS Survival Manual: A Step by Step Guide to Data Analysis Using SPSS for Windows. Fourth edn. Allen \& Unwin, NSW, Australia.

Podolny JM, Page KL. 1998. Network forms of organization. Ann Rev Socio 24: 57-76.

Partasasmita R, Hidayat RA, Erawan TS, Iskandar J. 2016. Local knowledge of Karangwangi Village people's, Cianjur District about variation (race), the keeping activity and conservation of chicken (Gallus gallus domesticus Linnaeus, 1758). Pros Sem Nas Masy Biodiv Indon. Andalas University, Padang, 23 April 2016. [Indonesian]

Partasasmita R, Iskandar J, Rukmana. 2017. Naga people's (Tasikmalaya District West Java, Indonesia) local knowledge of the variations and traditional management farm of village chickens. Biodiversitas 18: 834-843.

Sukabumi District Government. 2017. Geography of Sukabumi District. Sukabumi District Governmen, Pelabuhan Ratu. [Indonesian]

Sulandari S, Zein MSA, Paryanti S, Sartika T, Astuti M, Widjastuti T, Sujana E, Darana S, Setiawan I, Garnida D. 2007b. Local chicken genetic resources. In: Diwyanto K, Prijono SN (eds). The Biodiversity of Indonesia's Local Chicken Resources: Benefits and Potential. LIPI Press, Jakarta, Indonesia. [Indonesian]

Sulandari S, Zein MSA, Paryanti S, Sartika T. 2007a. Taxonomy and the origin of chicken domestication. In: Diwyanto K, Prijono SN. (eds). The Biodiversity of Indonesia's Local Chicken Resources: Benefits and Potential. LIPI Press, Jakarta, Indonesia. [Indonesian]

Sulandari S, Zein MSA, Sartika, T. 2008. Molecular characterization of Indonesian indigenous chicken based on mitochondrial DNA displacement (D)-loop sequences. J Biosci 5 (4) 145-154.

Šūmane S, Kunda I, Knickel K, Strauss A, Tisenkopfs T, des los Rios I, Rivera M, Chebach T, Askenazy A. 2017. Local and farmers' knowledge matters! How integrating informal and formal knowledge enhances sustainable and resilient agriculture. J Rural Stud. www.dx.doi.org/10.1016/j.jrurstud.2017.01.020.

Vanslembrouck I, Huylenbroeck GV, Verbeke W. 2002. Determinants of the willingness of Belgian farmers to participate in agrienvironmental measures. J Agric Econ 53 (3): 489-511.

Vik J, Stræte EG. 2017. Embedded competence: A study of farmers' relation to competence and Knowledge. Int J System Dynamics and Innovation in Food Networks 2017: 392-403. 